\title{
2 The 'liberation' truth is unmentionable in America
}

JOHN PILGER

Independent journalist

$\mathrm{I}_{\mathrm{r}}^{\mathrm{N}}$

$\mathrm{N}$ BAGHDAD, the rise and folly of rapacious imperial power is commemo rated in a forgotten cemetery called the North Gate. Dogs are its visitors; the rusted gates are padlocked, and skeins of traffic fumes hang over its parade of crumbling headstones and unchanging historical truth.

Lieutenant-General Sir Stanley Maude is buried here, in a mausoleum befitting his station, if not the cholera to which he succumbed. In 1917, he declared: 'Our armies do not come....as conquerors or enemies, but as liberators.' Within three years, 10,000 had died in an uprising against the British, who gassed and bombed those they called 'miscreants'. It was an adventure from which British imperialism in the Middle East never recovered.

Every day now, in the United States, the all-pervasive media tell Americans that their bloodletting in Iraq is well under way, although the true scale of the attacks is almost certainly concealed. Soon, more soldiers will have been killed since the 'liberation' than during the invasion. Sustaining the myth of 'mission' is becoming difficult, as in Vietnam. This is not to doubt the real achievement of the invaders' propaganda, which was the suppression of the truth that most Iraqis opposed both the regime of Saddam Hussein and the Anglo-American assault on their homeland. One reason the BBC's Andrew Gilligan angered Downing Street was that he reported that, for many Iraqis, the bloody invasion and occupation were at least as bad as the fallen dictatorship.

This is unmentionable in America. The tens of thousands of Iraqi dead and maimed do not exist. When I interviewed Douglas Feith, number three to Donald Rumsfeld at the Pentagon, he shook his head and lectured me on the 14 PACIFIC JOURNALISM REVIEW 92003 
'precision' of American weapons. His message was that war had become a bloodless science in the service of America's unique divinity. It was like interviewing a priest. Only American 'boys' and 'girls' suffer, and at the hands of 'Ba'athist remnants', a self-deluding term in the spirit of General Maude's 'miscreants'. The media echo this, barely gesturing at the truth of a popular resistance and publishing galleries of GI amputees, who are described with a maudlin, down-home chauvinism which celebrates the victimhood of the invader while casting the vicious imperialism that they served as benign. At the State Department, the under-secretary for international security, John Bolton, suggested to me that, for questioning the fundamentalism of American policy, I was surely a heretic, 'a Communist Party member', as he put it.

As for the great human catastrophe in Iraq, the bereft hospitals, the children dying from thirst and gastroenteritis at a rate greater than before the invasion, with almost 8 per cent of infants suffering extreme malnutrition, says Unicef; as for a crisis in agriculture which, says the Food and Agriculture Organisation, is on the verge of collapse: these do not exist. Like the American-driven, medieval-type siege that destroyed hundreds of thousands of Iraqi lives over 12 years, there is no knowledge of this in America: therefore it did not happen. The Iraqis are, at best, unpeople; at worst, tainted, to be hunted. 'For every GI killed,' said a letter given prominence in the New York Daily News late in June, '20 Iraqis must be executed.' In one week alone, Task Force 20, an 'elite' American unit charged with hunting evildoers, murdered at least five people as they drove down a street in Baghdad, and that was typical.

The august New York Times and Washington Post are not, of course, as crude as the News and Murdoch. However, on 23 July 2003, both papers gave front-page prominence to the government's carefully manipulated 'homecoming' of 20-year-old Private Jessica Lynch, who was injured in a traffic accident during the invasion and captured. She was cared for by Iraqi doctors, who probably saved her life and who risked their own lives in trying to return her to American forces. The official version, that she bravely fought off Iraqi attackers, is a pack of lies, like her 'rescue' (from an almost deserted hospital), which was filmed with night-vision cameras by a Hollywood director. All this is known in Washington, and much of it has been reported.

This did not deter the best and worst of American journalism uniting to help stage-manage her beatific return to Elizabeth, West Virginia, with the Times reporting the Pentagon's denial of 'embellishing' and that 'few people seemed to care about the controversy'. According to the Post, the whole affair had been 


\section{IRAQ AND THE MEDIA WAR}

'muddied by conflicting media accounts'. George Orwell described this as 'words falling upon the facts like soft snow, blurring their outlines and covering up all the details'. Thanks to the freest press on earth, most Americans, according to a national poll, believe Iraq was behind the 11 September attacks. 'We have been the victims of the biggest cover-up manoeuvre of all time,' says Jane Harman, a rare voice in Congress. But that, too, is an illusion.

The verboten truth is that the unprovoked attack on Iraq and the looting of its resources is America's 73rd colonial intervention. These, together with hundreds of bloody covert operations, have been covered up by a system and a veritable tradition of state-sponsored lies that reach back to the genocidal campaigns against Native Americans and the attendant frontier myths. Subsequent examples include the Spanish-American war, which broke out after Spain was falsely accused of sinking an American warship, the Maine, and war fever was whipped up by the Hearst newspapers; the non-existent 'missile gap' between the US and the Soviet Union, based on fake documents given to journalists in 1960 which served to accelerate the nuclear arms race; and four years later, the non-existent Vietnamese attack on two American destroyers in the Gulf of Tonkin for which the media demanded reprisals, giving President Johnson the pretext he wanted to bomb North Vietnam.

In the late 1970s, a silent media allowed President Carter to arm Indonesia as it slaughtered the East Timorese, and to begin secret support for the mujahedin, from which came the Taliban and al-Qaeda. In the 1980s, the manufacture of an absurdity, the 'threat' to America from popular movements in Central America, notably the Sandinistas in tiny Nicaragua, allowed President Reagan to arm and support terrorist groups such as the Contras, leaving an estimated 70,000 dead. That George W. Bush's America gives refuge to hundreds of Latin American torturers, favoured murderous dictators and antiCastro hijackers, terrorists by any definition, is almost never reported. Neither is the work of a 'training school' at Fort Benning, Georgia, whose graduates would be the pride of Osama Bin Laden.

Americans, says Time magazine, live in 'an eternal present'. The point is, they have no choice. The 'mainstream' media are now dominated by Rupert Murdoch's Fox television network, which had a good war. The Federal Communications Commission, run by Colin Powell's son Michael, is finally to deregulate television so that Fox and four other conglomerates control 90 per cent of the terrestrial and cable audience. Moreover, the leading 20 internet sites are now owned by the likes of Fox, Disney, AOL Time Warner and a clutch of 
other giants. Just 14 companies attract 60 per cent of the time all American webusers spend online.

The director of Le Monde Diplomatique, Ignacio Ramonet, summed this up well: 'To justify a preventive war that the United Nations and global public opinion did not want, a machine for propaganda and mystification, organised by the doctrinaire sect around George Bush, produced state-sponsored lies with a determination characteristic of the worst regimes of the 20th century.'

Most of the lies were channelled straight to Downing Street from the 24hour Office of Global Communications in the White House. Many were the invention of a highly secret unit in the Pentagon, called the Office of Special Plans, which 'sexed up' raw intelligence, much of it uttered by Tony Blair. It was here that many of the most famous lies about weapons of mass destruction were 'crafted'. On July 9, Donald Rumsfeld said, with a smile, that America never had 'dramatic new evidence' and his deputy Paul Wolfowitz earlier revealed that the 'issue of weapons of mass destruction' was 'for bureaucratic reasons' only, 'because it was the one reason [for invading Iraq] that everyone could agree on'.

\section{Murdoch has long wanted the BBC 'checked, broken up'}

The Blair Government's attacks on the BBC make sense as part of this. They are not only a distraction from Blair's criminal association with the Bush gang, though for a less than obvious reason. As the astute American media commentator Danny Schechter points out, the BBC's revenues have grown to \$5.6 billion; more Americans watch the $\mathrm{BBC}$ in America than watch $\mathrm{BBC} 1$ in Britain; and what Murdoch and the other ascendant TV conglomerates have long wanted is the BBC 'checked, broken up, even privatised...All this money and power will likely become the target for Blair Government regulators and the merry men of Ofcom, who want to contain public enterprises and serve those avaricious private businesses who would love to slice off some of the BBC's market share'. As if on cue, Tessa Jowell, the British Culture Secretary, questioned the renewal of the BBC's charter.

The irony of this, says Schechter, is that the BBC was always solidly prowar. He cites a comprehensive study by Media Tenor, the non-partisan institute that he founded, which analysed the war coverage of some of the world's leading broadcasters and found that the BBC allowed less dissent than all of them, including the US networks. A study by Cardiff University found much the same. More often than not, the BBC amplified the inventions of the lie machine in Washington, such as Iraq's non-existent attack on Kuwait with scuds. And there 


\section{IRAQ AND THE MEDIA WAR}

was Andrew Marr's memorable victory speech outside 10 Downing Street: '[Tony Blair] said that they would be able to take Baghdad without a bloodbath, and that in the end the Iraqis would be celebrating. And on both those points he has been proved conclusively right.'

Almost every word of that was misleading or nonsense. Studies now put the death toll at as many as 10,000 civilians and 20,000 Iraqi troops. If this does not constitute a 'bloodbath', what was the massacre of 3,000 people at the Twin Towers?

In contrast, I was moved and almost relieved by the description of the heroic Dr David Kelly by his family. 'David's professional life,' they wrote, 'was characterised by his integrity, honour and dedication to finding the truth, often in the most difficult circumstances. It is hard to comprehend the enormity of this tragedy.' There is little doubt that a majority of the British people understand that David Kelly was the antithesis of those who have shown themselves to be the agents of a dangerous, rampant foreign power. Stopping this menace is now more urgent than ever, for Iraqis and us.

John Pilger, an Australian, is a London-based war correspondent and filmmaker. His film on Iraq, Paying the Price: Killing the Children of Iraq, was shown in many countries, including New Zealand, in 2000. He has his own website:

www.johnpilger.com 
Copyright of Pacific Journalism Review is the property of Auckland University of Technology and its content may not be copied or emailed to multiple sites or posted to a listserv without the copyright holder's express written permission. However, users may print, download, or email articles for individual use.

http://Mww.aut.ac.nz/depts/commstud/journ/pjrsubs.shtml 